Inevitably in a book of this kind the reader will sometimes feel frustration at unattributed statements, but a reading list is given at the end of each chapter.

The book, although expensive, is enjoyable and useful. Young research workers in particular should find it helpful as a source of information and ideas, and as a means of sharpening their teeth. Their own efforts at the bench should ensure that their feet remain on the ground.

G. R. SMITH

\title{
The bacteria
}

Edited by I. C. Gunsalus, J. R. Sokatch and L. N. Ginstow. 1979. Volume 7: mechanisms of adaptation. New York, San Francisco and London: Academic Press. Pp. xx and 593. US\$45.00.

The publication of the first volume of the treatise The bacteria, edited by Gunsalus and Stanier, in 1960 was timely because it approximately coincided with the evolution of microbiology as a separate discipline in science faculties in Britain. Previously the centres of the field had been in medical faculties. Although microbiology in the USA was similarly tied to the medical faculties, scientists there had shown a more catholic approach than the universities in Western Europe and the treatise The bacteria was one of the fruits of the American experience. The original treatise provided an authoritative approach to the procaryotic microbes although the procaryote-eucaryotic division has emerged since.

One impression of this volume 7 of the treatise is of the immense amount of knowledge that has been accumulated since 1960 . Of the nine chapters, seven have analogous counterparts in volume 1 of the series. These chapters cover spores, cell surfaces, cell appendages, cell walls and bacterial viruses. Only two new topics, nitrogen fixation and chemotaxis, are added in the latest volume. This approach is disappointingly static. The new volume is subtitled Mechanisms of adaptation whereas the first volume was entitled Structure. The change in the title is misleading.

Some of the articles are massive. Those on the structure and biosynthesis of cell walls and the outer membranes of gram-negative bacteria by Tipper and Wright cover nearly 200 pages and clearly constitute a monograph on their own. There are other extensive articles on spores by Dworkin, chemotaxis by Koshland, permeation of cell surfaces by Saier, cell appendages by Sokatch. Other subjects are given light treatment. The excitement of developments in chemotaxis are conveyed although there was a tendency for the excitement to give way to euphoria. The account of the control of cell division by Helmstetter, Pierucci, Weinberger, Holmes and Tang is timely. It gave the impression that studies in this field have reached an impasse. Could this be because the division event essentially is only one, possibly minor, of the many that make up the cell cycle? If so, the impasse may be generated by attempting to regard cell division in isolation.

This volume is a valuable work of reference for the general microbiologist and definitively treats the present position of most of the subject matter. The diligent creative research of the many bacteriologists whose work is cited calls for our admiration. The retirement of Stanier from the team of editors is a matter for regret. No doubt he will remain a source of inspiration to the new editors.

S. J. PIRT

\section{Adhesion of microorganisms to surfaces}

Edited by D. C. Ellwood, J. Melling and P. Rutter. 1979. Special Publications of the Society for General Microbiology 2. London, New York and San Francisco: Academic Press. Pp. ix and 216. $£ 10.00$

In reviews of microbial pathogenicity an analogy is sometimes made to life in a flowing stream. The pathogens that involve mucosal surfaces will be swept away unless they become attached to the host's cells. Most of the contributors to this symposium apparently share the belief that concepts introduced by physical chemists will explain the way in which bacteria adhere to surfaces. Biologists have profited before from the ideas of physical chemists though 